Papers and Proceedings of the Royal Society of Tasmania, Volume 113, 1979

(ms. received 21.4 .1978 )

\title{
TOWARDS A HUMAN PREHISTORY IN THE LOWER DERWENT RIVER AREA, SOUTH-EASTERN TASMANIA, AUSTRALIA
}

\author{
by Jim Stockton ${ }^{1}$ and Alan Wallace 2 \\ ${ }^{1}$ National Parks and Wildife Service and ${ }^{2}$ University of Tasmania
}

(with one table and one text-figure)

ABSTRACT

STOCKTON, J. and WALLACE, A., 1979 (20 vii): Towards a human prehistory in the lower Derwent River area, south-eastern Tasmania, Australia. Pop. Proc. R. Soc. Tasm., 113: 81-84. ISSN 0080-4703. National Parks and Wildlife Service, Magnet Court, Sandy Bay Tasmania and Department of Anatomy, University of Tasmania, Hobart, Tasmania, Australia.

A review of the published and unpublished reports on the archaeology of the lower Derwent River area, south-eastern Tasmania, Australia is presented.

\section{THE PROBLEM}

The current gap in the archaeological sequence of the Derwent is the recent period. There is a dearth of ethnohistorical data for the area during the early years of settlement. Work done in the area to date has been haphazard, and has lacked an overall research goal perspective. Most excavators have been pre-occupied with the maximum antiquity rather than the delineation of a regional archaeological sequence.

\section{OLD BEACH}

An 01d Beach site was excavated by Sigleo (1975) (fig. 1).

old Beach is located approximately $18 \mathrm{~km}$ north of Hobart on the eastern margin of the Derwent estuary. Geomorphological investigations of source bordering sand sheets in the lower Derwent Valley during 1971-73 revealed the presence of several artifacts in a trench at $01 \mathrm{~d}$ Beach. The site which borders the confluence of the River Jordan at Herdsmans Cove with the estuary of the Derwent was excavated by Sigleo and Colhoun, 1975 (fig. 1). The stratigraphic position of the artifacts suggested that this site could provide evidence for the oldest human occupation in south-eastern Tasmania. The artifacts in Sigleo's Unit 3 suggest a Late Pleistocene age for Man in Tasmania. This period of occupation predates $9000-11000$ BP by an unknown amount. In Sigleo's Unit 2 two hearths were sectioned and charcoal and shells of the common edible mussel Mytizus planulatus were dated by C14. The dates obtained were $5800 \pm$ 130 (SUA - 306) and $5600 \pm 130 \mathrm{BP}$ (SUA - 306) and $5600 \pm 100 \mathrm{BP}$ (SUA - 307). The dated hearths associated with Sigleo's Unit 2 and the truncated surface of Unit 3 suggest that a relatively continuous phase of Aboriginal occupation had commenced in this area by at least 5800 radiocarbon years ago.

Reber (1965, p.266) dated a site on a small peninsula on the east side of the Derwent River opposite Dogshear Point. The midden was about 9m A.S.L. and covered an area of several hundred $\mathrm{m}^{2}$. The sample was taken from $1.37 \mathrm{~m}$ below the surface and dated $5200 \pm 110$ years BP $(1-324)$.

\section{SHAG BAY}

Shag Bay, is a few hundred metres north of Geilston Bay (Tasmanian Aboriginal Sites Index Card No. 18) (fig. 1) and directly opposite New Town near the city of 

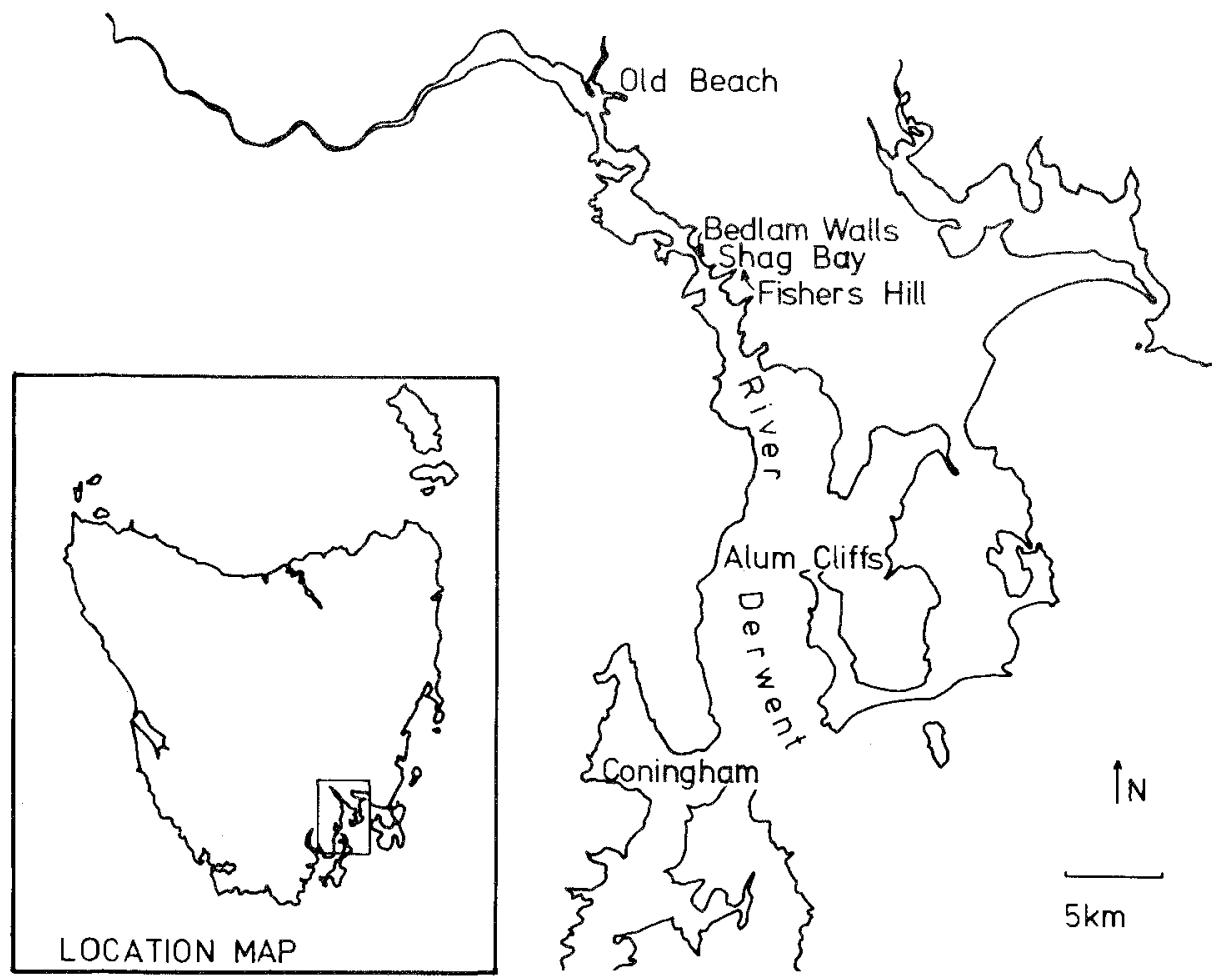

FIG. 1.- Map showing excavated sites in the Derwent estuary.

Hobart. It is $24 \mathrm{~km}$ from the mouth of the estuary. Musse1s, Mytilus planulatus, and the common mud oyster, Ostrea angasi, are the largest of the shellfish known to have lived in this part of the Derwent estuary, though several small species have been observed.

Nearly $2 \mathrm{~km}$ of steep, horizontally-bedded 30 metre high mudstone cliffs mark the eastern shore of the estuary immediately north of Geilston Bay. Midway along this cliff (The Bedlam Walls) 100 metres to the south of Shag Bay, is a series of rockshelters, many of which show evidence of Aboriginal occupation in the form of mussel she11s eroding out of the floor deposits. The rock shelter chosen by Vanderwal (1977) for excavation is $15 \mathrm{~m}$ above the level of the river. It is the largest and most accessible of those in the cliff being $12 \mathrm{~m}$ long and $4 \mathrm{~m}$ deep. It has a westerly aspect across the Derwent River. Carbon samples were collected from near the top of the occupation zone (SB 2/7, GaK 5424: $4720 \pm 110$ years BP) and another from the base (SB 2/15, GaK $5425: 5300 \pm 120$ years BP). The date difference of 700 years suggests that the rockshelter was used for probably less than 1000 years. Shag Bay rockshelter was seen by Vanderwal as an extreme example of the east coast pattern of intensive single resource utilisation and nomadism. 
Jim Stockton and Alan Wallace

FISHERS HILL

An open midden on Fishers Hill was excavated by Wallace in 1973 (fig. 1). The area is immediately south and east of Shag Bay and is part of the area often also referred to as Bedlam Walls. The site excavated was on the shoulder of a hill near the $50 \mathrm{~m}$ contour facing north-west across Shag Bay. No clear margin of the deposit existed but the midden was oval in shape and covered about $60 \mathrm{~m}^{2}$. The first part of the excavation near the centre of the deposit showed $0.54 \mathrm{~m}$ of midden deposit resting on the mudstone bedrock. Four ill-defined layers were recorded. No artifacts were recovered in this pit.

A feature of this excavation was the absence of any transitional zone of she11free earth above the bedrock. A second pit $3 \mathrm{~m} \times 1 \mathrm{~m}$ was therefore excavated which proved $0.1 \mathrm{~m}$ of topsoil on $0.38 \mathrm{~m}$ of shell midden which in turn lay on the mudstone bedrock. The shell deposit was lenticular in section, and beyond it the topsoil graded through to bedrock. Several stone artifacts were found. This site is interpreted as a meal site of temporary nature which was repeatedly visited. The bottom of the deposit was dated by C14 as follows: She1l carbonate $5420 \pm 85$ BP (ANU 1090 A), acid insoluble organic fraction $5890 \pm 90$ (ANU 1090 B) years BP. These dates show that this site is close in time to the Shag Bay site, the old Beach site and Reber's site 12 near old Beach.

\section{ALUM CLIFFS}

An open midden site at Alum Cliffs, Kingston, was excavated by Stockton in 1975 (Tasmanian Aboriginal Sites Index Card No. 20) (fig. 1). The site was c. $600 \mathrm{~m}^{2}$ in area and $0.5 \mathrm{~m}$ deep. It was hoped that this site would be of similar antiquity to sites excavated higher up the Derwent but that it would represent a fully marine resource zone. Marine shel1s were recovered throughout the deposit. Stone artifacts, a piece of ochre, and a scallop she11 with a hole in the centre were recovered. The bottom of the deposit rested on the siltstone bedrock, and charcoal from it dated $3875 \pm 160$ BP (SUA - 599).

\section{CONINGHAM}

The Coningham site was excavated by Stockton and Wallace in 1976 (Wa1lace and Stockton, 1979) as a rescue excavation of eroding skeletal material (Tasmanian Aboriginal Sites Index Card No. 126). It is located on the bank above a beach on the side of the D'Entrecasteaux Channel. The sandy beach is approximately $300 \mathrm{~m}$ 1ong and has cliffs at either end. A gully meets the beach about $15 \mathrm{~m}$ from the area excavated. The vegetation adjacent to the site is open dry eucalypt forest, probably altered by European land use. This occurrence is significant because so little of the Tasmanian skeletal material has been excavated with archaeological control from an undamaged site.

There is no sign of bone-burning, a hearth or a pit for burial. Some of the large mud oyster shells near the body were standing on edge rather than lying flat as is usua1. They appeared to form an incomplete circle. The body was then disturbed by the carnivores which led to the breaking of long bones and displacement of the bone fragments. The bones were then gradually covered by sand blown from the beach, a process still continuing. A charcoal sample associated with the skeletal material dated $840 \pm 95 \mathrm{BP}$ (SUA - 626), the youngest date so far obtained for the Derwent estuary.

\section{BEDLAM WALLS SURVEY}

Jacklyn (1975) has made an intensive survey of the Bedlam Walls area (fig. 1) 
and collected more than 600 artifacts. This shows the high density of occupation sites for this area.

TABLE 1

DATA FROM BEDLAM WALLS SURVEY

Type of Site

Number

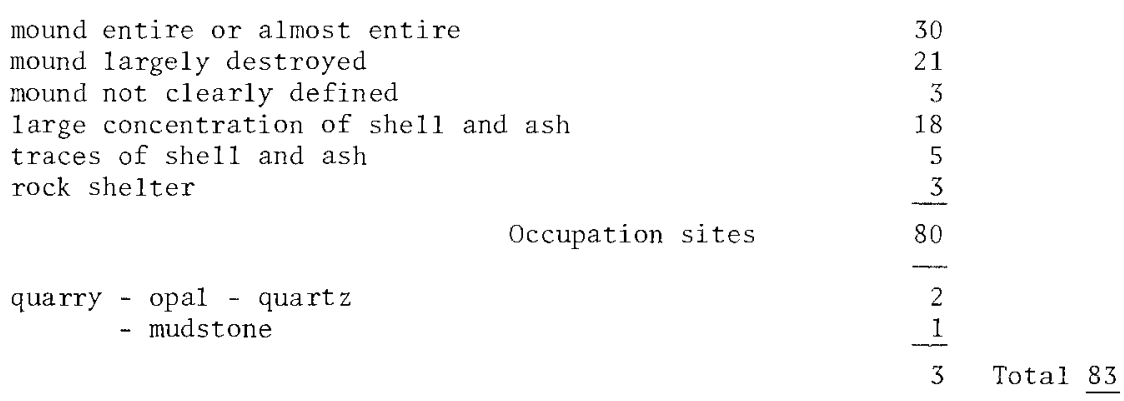

COMMENT

This paper has collated archaeological work in the lower Derwent area using much previously unpublished material. There is a need for new sites covering the past four millenia to fill in the prehistory of Aboriginal occupation.

\section{REEERENCES}

Jacklyn, R.M., 1975: Bedlam Walls Occupation Sites. Unpublished Report. Reber, G., 1965: Aboriginal Carbon Dates from Tasmania. Markind, 6(6): 264-268.

Sigleo, W.R. and Colhoun, E.A., 1975: Glacial Age for Man in Southeastern Tasmania : Evidence from the old Beach Site. Search, 6(7): 300-302.

Tasmanian Aboriginal Sites Index. National Parks and Wildife Service, Hobart. Vanderwal, R.L., 1977: The Shag Bay Rock Shelter, Tasmania. The Artefact, 2(4): $161-70$.

Wallace, A.G. and Stockton, J., 1979: Skeletal Remains at Coningham, Tasmania, Australia. Pap. Proc. R. Soc. Tasm., 113: 149-153. 